\title{
Retrogression of Orthopyroxene-bearing Gneiss of Iboropa Akoko, Southwestern Nigeria
}

\section{Retrogresija gnajsa z ortopiroksenom iz območja Iboropa Akoko, jugozahodna Nigerija}

\author{
E.J. Oziegbe ${ }^{1, *}$, V.O. Olarewaju ${ }^{2}$, O.O. Ocan ${ }^{3}$, G.Costin ${ }^{4}$ \\ ${ }^{1}$ Department of Geosciences, Faculty of Science, University of Lagos, Nigeria \\ ${ }^{2}$ Department of Geology, Obafemi Awolowo University, Nigeria \\ ${ }^{3}$ Department of Geological Science, College of Science, Engineering and Technology, Osun State University, Nigeria \\ ${ }^{4}$ Earth, Environmental and Planetary Sciences, Rice University, Texas, USA \\ * eoziegbe@unilag.edu.ng
}

\begin{abstract}
In this article, we report the mineral chemistry and petrographic features of charnockitic exposure of Iboropa within Precambrian Basement Complex of Nigeria. The mineral assemblages are pyroxene, plagioclase, biotite, hornblende, alkali feldspars, microperthite, quartz and ilmenite, with apatite occurring as accessory mineral. Apatite occurs in abundance as euhedral crystals. Orthopyroxene observed is strongly pleochroic and has numerous microfractures, and it is hypersthene $\left(\mathrm{En}_{45} \mathrm{Fs}_{54} \mathrm{Wo}_{1}\right)$ with low $\mathrm{TiO}_{2}$ and $\mathrm{MnO}$, having extremely low percentage of $\mathrm{CaO}$. Hypersthene is mantled by a complex corona of amphibole, and the amphibole is hornblende with a chemical formula: $(\mathrm{K}, \mathrm{Na})(\mathrm{Ca}, \mathrm{Fe})_{2}$ $(\mathrm{Fe}, \mathrm{Mg}, \mathrm{Al}, \mathrm{Ti})_{5}(\mathrm{Al}, \mathrm{Si})_{8} \mathrm{O}_{22}(\mathrm{OH})_{2}$. Plagioclase occurs as inclusions in both pyroxene and biotite. Biotite has high concentration of $\mathrm{TiO}_{2}$ and extremely low $\mathrm{CaO}$. The opaque mineral observed is ilmenite and it is concentrated around hypersthene and amphibole. Rare earth element (REE) displays negative Eu anomaly with enrichment of light REE over heavy REE. Amphiboles surrounding orthopyroxene are evidences of retrograde reactions and are formed at the expense of orthopyroxene reacting with plagioclase and quartz in the presence of fluid. The relationship between the mineral assemblages suggests the retrogression of the gneiss that might be as a result of rehydration process, and it is a transition from granulite facies to amphibolite facies during a retrogressive form of metamorphism.
\end{abstract}

\section{Povzetek}

$\mathrm{V}$ tem članku predstavljamo mineraloško-kemične in petrografske značilnosti charnokita, ki se pojavlja na območju Iboropa znotraj predkambrijske podlage Nigerije. Opazovani minerali so: piroksen, plagioklaz, biotit, rogovača, alkalijski glinenec, mikropertit, kremen in ilmenit, z apatitom ki se pojavlja kot akcesorni mineral. Apatit je akcesorni mineral in se pojavlja v obilju kot evhedralni kristal. Opazovan ortopiroksen je močno pleokroičen in ima številne mikrorazpoke. Je hipersten $\left(\mathrm{En}_{45} \mathrm{Fs}_{54} \mathrm{Wo}_{1}\right)$ z nizkim $\mathrm{TiO}_{2}$ in $\mathrm{MnO}$ in ima ekstremno nizek delež CaO. Hipersten je oplaščen s kompleksno korono amfibola, ki je rogovača s kemijsko formulo $\quad(\mathrm{K}, \mathrm{Na})(\mathrm{Ca}, \mathrm{Fe})_{2}(\mathrm{Fe}, \mathrm{Mg}, \mathrm{Al}, \mathrm{Ti})_{5}(\mathrm{Al}, \mathrm{Si})_{8} \mathrm{O}_{22}(\mathrm{OH})_{2}$. Plagioklaz se pojavlja kot inkluzije v piroksenu in biotitu. Biotit ima visoko koncentracijo $\mathrm{TiO}_{2}$ in ekstremno nizko CaO. Opazovan nepreseven mineral je ilmenit in je koncentriran okoli hiperstena in amfibola. REE kaže na negativno Eu anomalijo z obogatitvijo LREE nad HREE. Amfiboli, ki obkrožajo ortopiroksene, so dokaz retrogradne reakcije in nastanejo pri reakciji ortopiroksena s plagioklazom in kremenom v prisotnosti fluida. Razmerje med mineralno sestavo predlaga retrogresijo gnajsa, ki bi lahko bila rezultat rehidracijskega procesa in je prehod granulitnega faciesa $v$ amfibolitni facies med retrogresivno obliko metamorfizma.

Ključne besede: hipersten, mikro razpoke, retrogradno, mokropertit, rehidracija.

Keywords: Hypersthene, microfractures, retrograde, microperthite, rehydration. 


\section{Introduction}

Orthopyroxene-bearing gneiss is usually referred to as charnockitic gneiss or granulite, most especially if the orthopyroxene is hypersthene. In this article, the use of the term charnockitic gneiss will be adhered to. Charnockite are hypersthene-bearing rocks [1]. There has been an extensive study on charnockites and charnockitic rocks in India [2-5]. Charnockites are orthopyroxene-bearing anhydrous granitoids [1,6], and they are of magmatic or metamorphic origin [7]. Charnockites are restricted to high-grade belt and those that are of metamorphic origin take their source either from igneous or from sedimentary protoliths during high-grade metamorphism under anhydrous conditions [8]. In some parts of south India and Sri Lanka, 'patchy' charnockites have been termed as 'arrested growth', 'in situ' charnockites or charnockitisation of amphibolite facies [9-15]. For the patchy charnockites of east Gondwana, metamorphic transformation from amphibolite facies gneiss occurred by two mechanisms: $\mathrm{CO}_{2}$ ingress from deep level and a drop in the pressure of fluid $[11,16-18]$. The process of charnockitisation is propagated by the influx of the $\mathrm{CO}_{2}-\mathrm{H}_{2} \mathrm{O}$ fluid, which results in the migration of most basic elements from the initial rock towards the transition zones [19]. Touret and Huizenga [20] studied charnockite microstructures from magmatic to metamorphic and realised that microstructures alone cannot always provide solution to the igneous or metamorphic origin of charnockites due to high temperature of recrystallisation. In their study, further evidence for the presence of brine fluids includes the high-temperature fluid-mineral reactions at inter-grain boundaries (K-feldspar microveins and myrmekites) observed in both igneous and metamorphic charnockites. Yang et al. [21] gave the first report of Paleoproterozoic incipient charnockite from the North China Cratons. They documented centimetre- to decimetre-scale anhydrous zones of incipient charnockite within tonalitetrondhjemite-granodiorite (TTG) rocks that are adjacent to an intrusive charnockite. From their study, they concluded that the incipient charnockite formed at ultrahigh-temperature conditions of $890^{\circ} \mathrm{C}-970^{\circ} \mathrm{C}$.

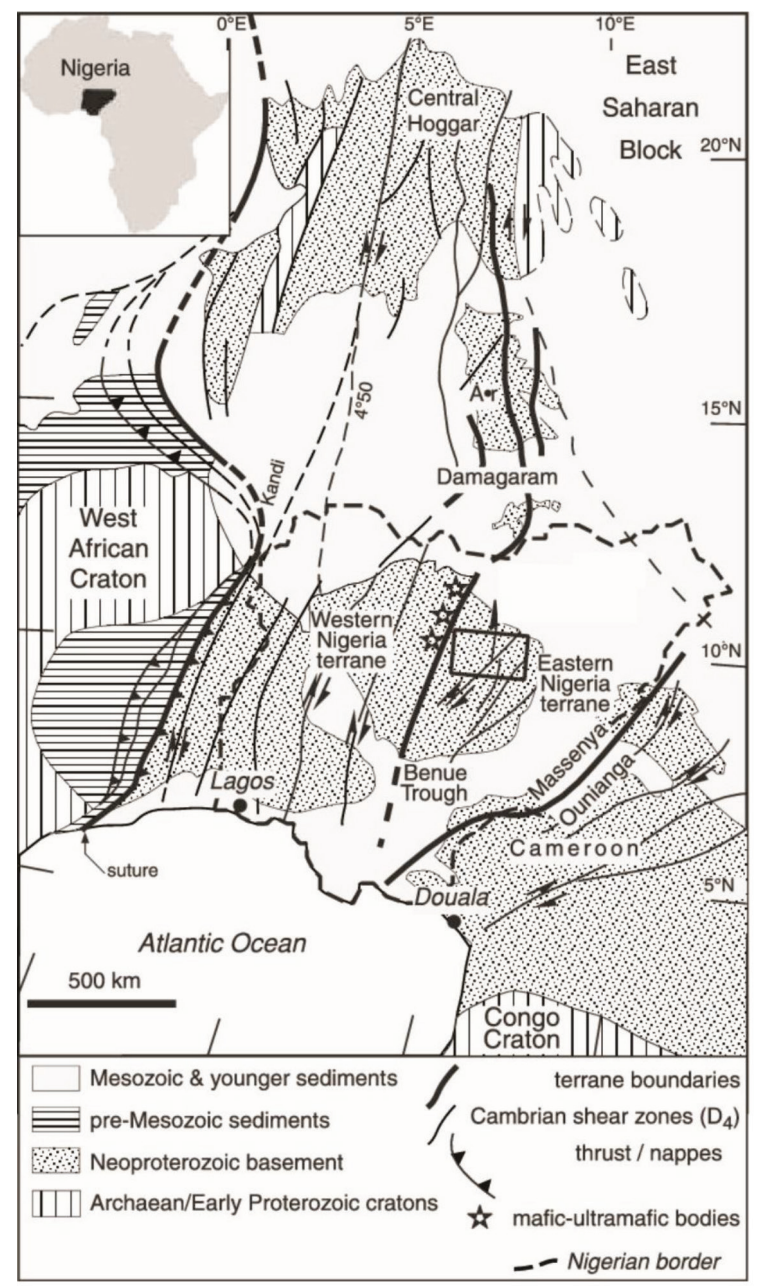

Figure 1. Sketch geological map of the Hoggar-Air-Nigeria Province showing the Neoproterozoic Trans-Saharan belt, resulting from terrane amalgamation between the cratons of West Africa and Congo and the East Saharan block [26].

The study area for this research is part of the Neoproterozoic basement of Nigeria (Figure 1). Rocks of the Basement Complex of Nigeria are made up of predominantly migmatitic and granitic gneisses; quartzites; slightly migmatised to unmigmatised meta-sedimentary schists and meta-igneous rocks; charnockitic, gabbroic and dioritic rocks and members of the Older Granite suite mainly granites, granodiorites and syenites [22]. The migmatite gneisses of South-Western Nigeria are usually composed of three components, all of which sometimes may be present in a single outcrop [22]. These components are (a) early gneiss, (b) mafic-ultramafic bands and (c) granitic or felsic components. Iboropa Akoko is about $10 \mathrm{~km}$ from 


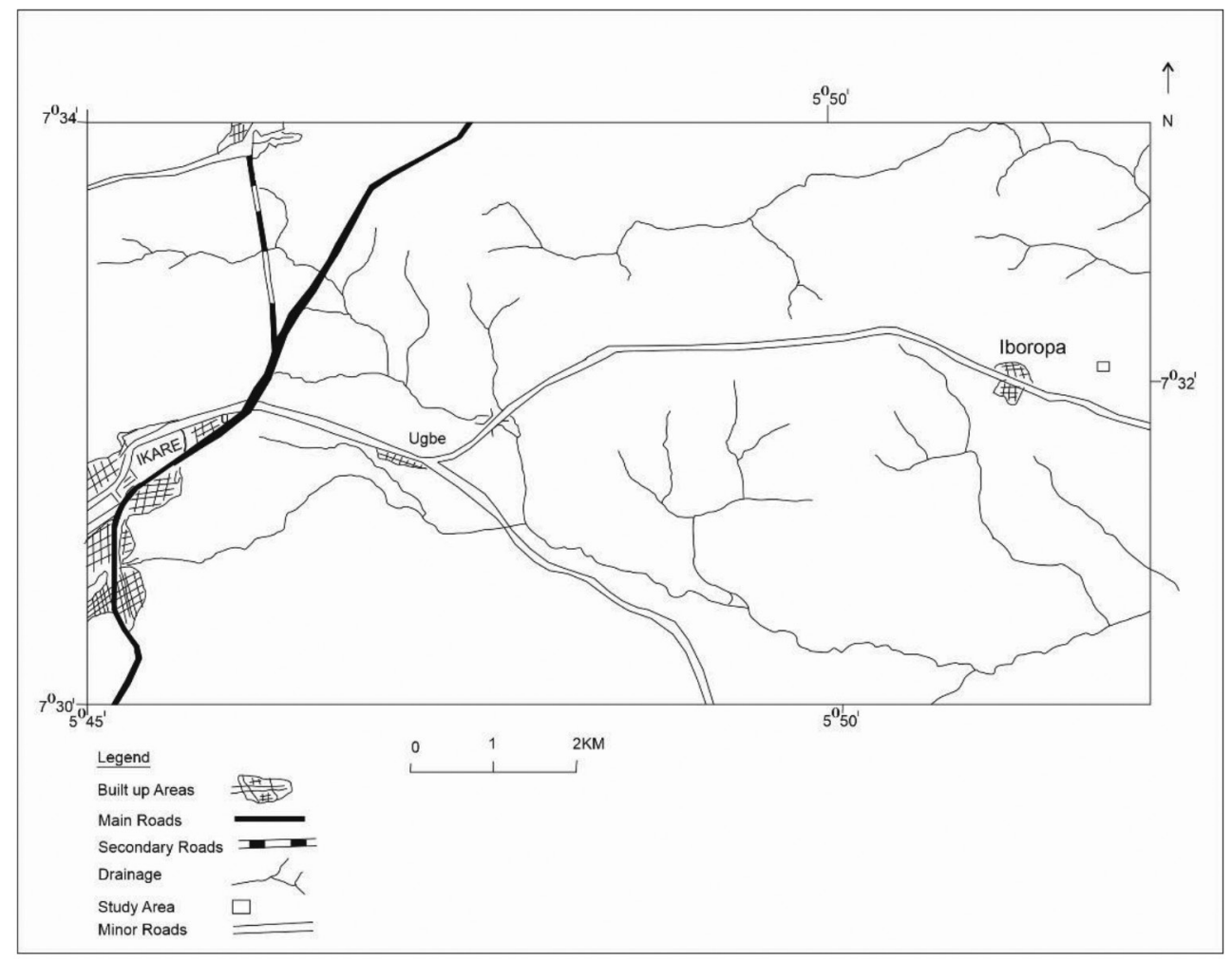

Figure 2. Location map of the study area.

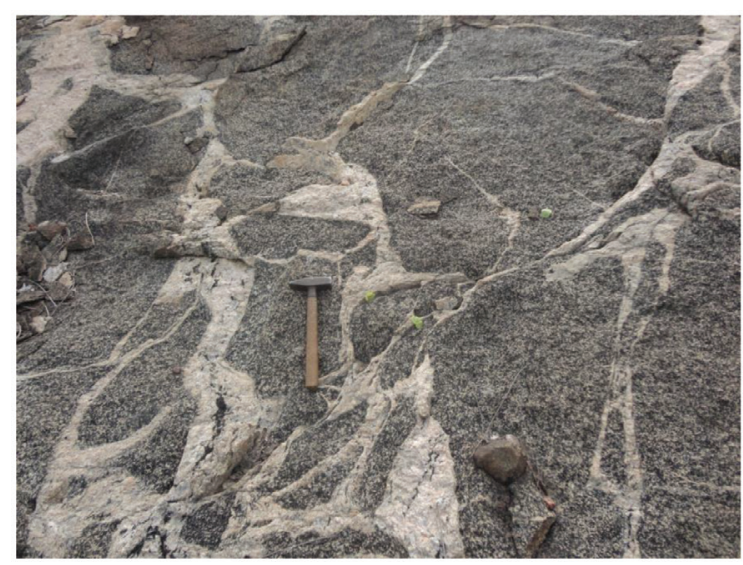

Figure 3. Field photograph of charnockitic gneiss with quartzo-feldspathic material at Iboropa Akoko.

Ikare (Figure 2), and Ikare area is dominated by migmatite gneiss-quartzite complex, making up $90 \%$ of the rock units [23]. The charnockitic gneiss of Iboropa is dark grey in colour (Figure 3 ), and it is poorly foliated. Other associated rocks in this area are grey gneiss, granitic gneiss, pelitic gneiss and pegmatite. Almost all granulite facies rocks described so far from the
Nigerian Basement Complex are of charnockitic affinity. Rocks of the granulite facies are found in all crystalline basement of the world [24]. Hubbard [25] suggested that these granulite facies rocks represent relicts of an earlier and more widespread granulite facies metamorphism of unspecified age, predating the Pan-African Orogeny.

However, Rahaman and Ocan [23] suggested that the charnockitic rocks were original igneous rocks that retained their anhydrous affinity during the Pan-African Orogeny. Most of the other rocks of the basement complex described so far range in metamorphic grades from greenschist to upper amphibolite facies. Metamorphic rocks that have attained higher grades of metamorphism are probably the cordierite-sillimanite gneisses at Bena village in northern Nigeria, which Sacchi [27] ascribed to the granulite facies. On the published 1:250,000 G.S.N. Sheets 61, Akure, some localities within the migmatite gneiss-quarzite complex were indicated by Dempster [28] as containing granulite facies mineral paragenesis. Petrographic evidence presented strongly suggests that the 
granulite facies mineral paragenesis in Ikare area is a result of prograde metamorphism [29]. In this respect, rocks of the granulite facies mineralogy in Ikare area are different from others of similar mineralogy described so far [23], as original igneous rocks, because of composition, especially low water content, retained their original (igneous) granulite facies mineralogy. Data used for this work are from the PhD thesis of the first author.

\section{Materials and Methods}

Detailed petrography was carried out using Petrographic Microscopes, both at the Department of Geology, Obafemi Awolowo University and Department of Geology, Rhodes University, South Africa. Major elements and trace elements were determined at the Central Analytical Facility (CAF), Stellenbosch University, South Africa, using X-ray fluorescence (XRF) and laser ablation ICP-MS, respectively. The mineral chemistry of the minerals was done using electron microprobe analysis (EPMA) at the Department of Geology, Rhodes University South Africa by a JEOL JXA 8230 Superprobe, using 4 WD spectrometers. Equipment operating conditions employed for the EPMA were $15 \mathrm{kV}$ acceleration voltage, $20 \mathrm{nA}$ probe current, beam size of $\sim 1 \mu \mathrm{m}$ and counting time $10 \mathrm{~s}$ on peak and $5 \mathrm{~s}$ on each lower and upper background, respectively. Natural standards were used for measuring the characteristic X-rays, and the ZAF matrix correction method was employed for quantification.

\section{Results}

\section{Petrography}

The charnockitic gneiss is granoblastic in texture. The minerals that are present in the charnockitic gneiss include pyroxenes, amphiboles, biotite, plagioclase feldspar, K-feldspar quartz, opaque minerals, while apatite occur as accessory mineral. Orthopyroxene occur as porphyroblasts, changing from colourless to grey, highly pleochroic and changing from grey to pinkish, a property indicative of hypersthene (Figure 4). Some of the porphyroblasts have
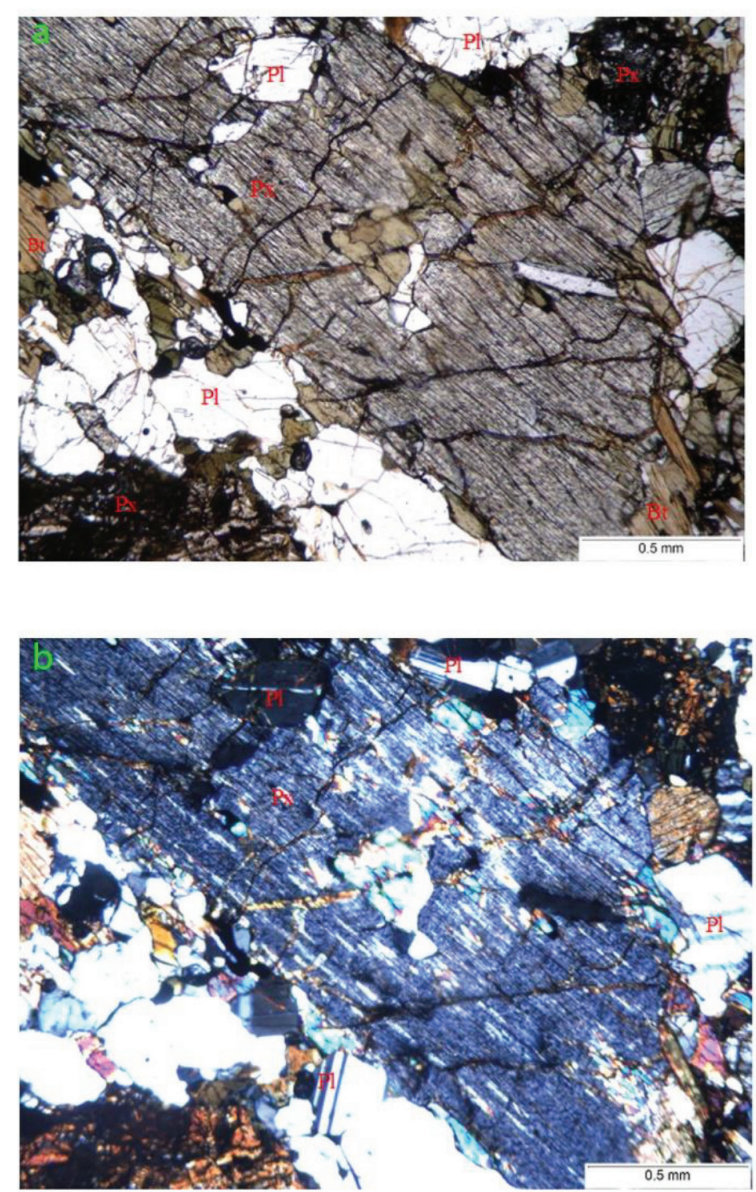

Figure 4. Photomicrographs showing (a) porphyroblast of pyroxene (Px) having numerous fractures. Pale biotite (Bt) along cleavage planes (PPL). (b) Plagioclase (PI) occurring as inclusions in pyroxene (XPL). PPL, plane polarised light; XPL, crossed polarised light.

inclusions of plagioclase and biotite (Figure 4) which make them poikiloblastic in texture. There is rimming of pyroxene by amphibole (Figure 5a). Back scattered electron (BSE) image and elemental maps in Figure $5 \mathrm{a}$ are also presented (Figures $5 \mathrm{~b}$ and 6 ). There are small patches of pale-coloured biotite along the cleavage planes of pyroxenes (Figure 4a). Amphibole occurs as large, xenoblastic, dark green crystals and it is strongly pleochroic with inclusions of pyroxene (Figure 7a and 7b). Also, amphiboles have close association with opaque minerals. Biotite observed is of two varieties, namely the light brown and the deep brown, and both are strongly pleochroic. The longer axes of biotite are slightly aligned in preferred orientations 


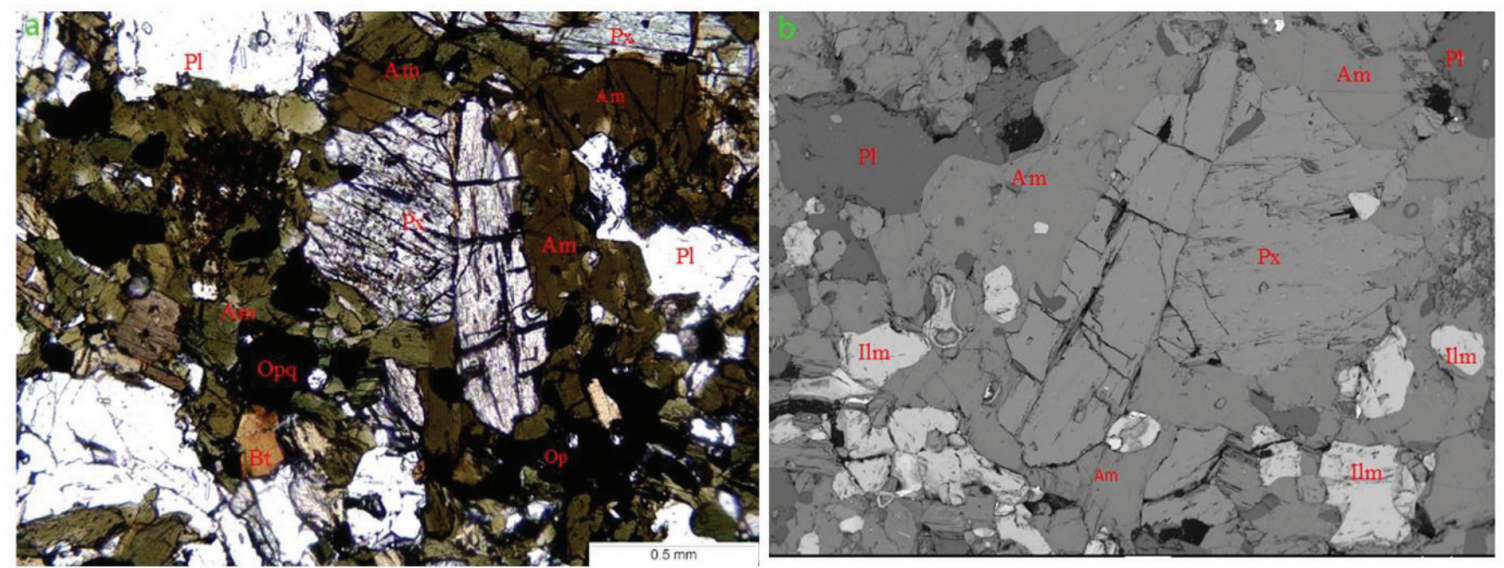

Figure 5. (a) Photomicrograph showing pyroxene (Px) rimmed by amphibole (Am). The opaque mineral (Opq) (PPL). (b) Backscattered electron image of minerals shown in (a). PPL, plane polarised light; XPL, crossed polarised light.

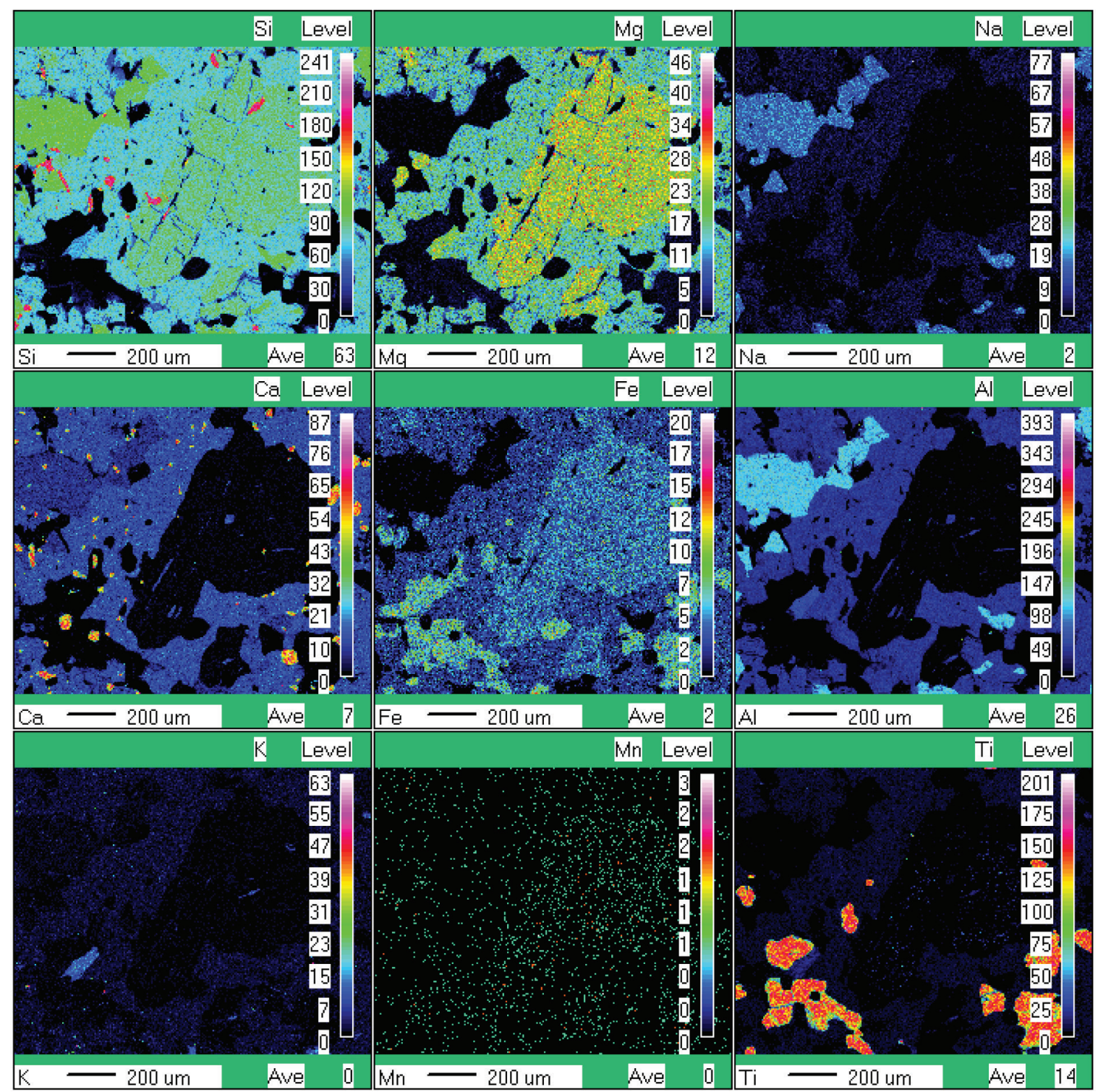

Figure 6. The compositional maps of minerals shown in Figure 5, showing elemental levels of Si, $\mathrm{Mg}, \mathrm{Na}, \mathrm{Ca}, \mathrm{Fe}, \mathrm{Al}, \mathrm{K}, \mathrm{Mn}$ and Ti. 

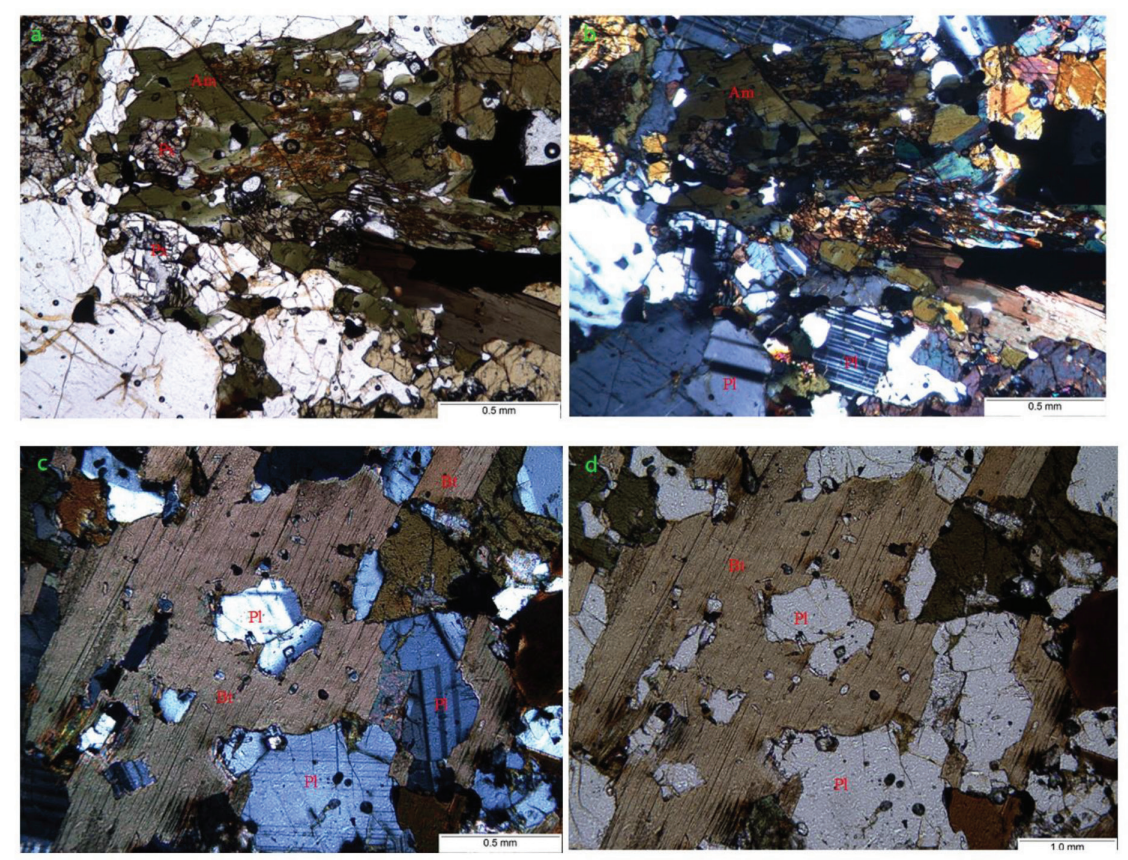

Figure 7. Photomicrographs showing: (a) amphiboles (Am) with inclusions of pyroxene (Px) (PPL). (b) Amphiboles with inclusions of pyroxene, surrounded by plagioclase (PI) (XPL). (c) Biotite having inclusions of plagioclase feldspar (XPL). (d) Biotite having inclusions of plagioclase feldspar (PPL). PPL, plane polarised light; XPL, crossed polarised light.

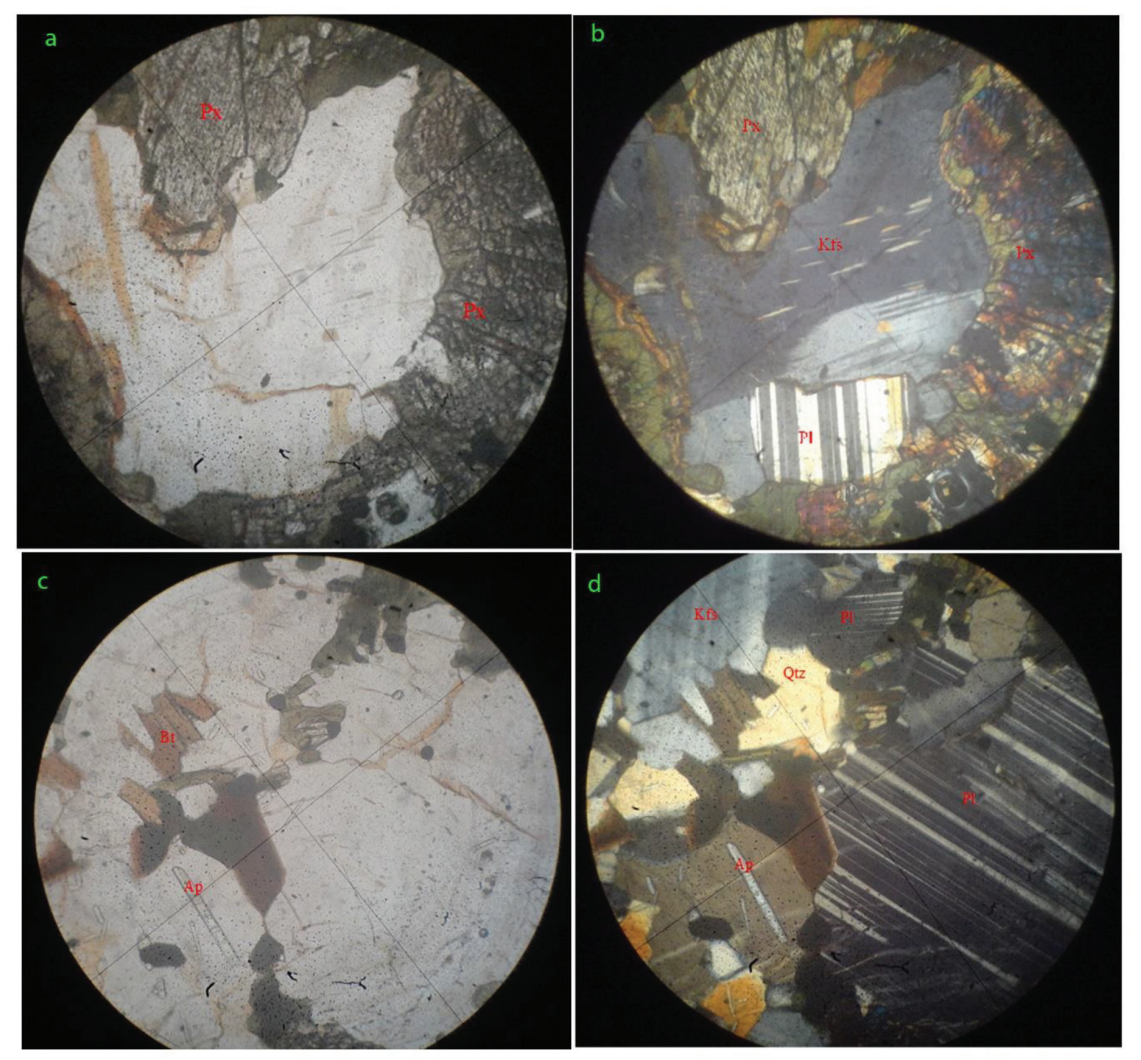

Figure 8. Photomicrographs showing: (a) pyroxene in close contact with areas occupied by transparent minerals: plagioclase and K-feldspar. Altered biotite (brownish mineral) surrounded by transparent mineral (PPL). (b) Pyroxene (Px), perthitic K-feldspar (Kfs) and plagioclase feldspar (PI). The straight lamellae in the perthite (XPL). (c) Biotite (Bt) and apatite. The smaller needleshaped apatite crystals (PPL). (d) K-feldspar (Kfs), quartz (Qtz), apatite (Ap) and plagioclase (PI) (XPL). PPL, plane polarised light; $X P L$, crossed polarised light. 
which thus defines the foliation. The biotite grains have inclusions of plagioclase and apatite (Figure 7c and 7d). Plagioclase occurs as porphyroblasts, and grains are almost equidimensional. Plagioclase crystals observed exhibit both ablite and carlsbard twinning. There is a close association between plagioclase and pyroxene. Plagioclase occurs as inclusions in both pyroxene and biotite, and plagioclase crystals occur at the margins of amphiboles. K-feldspar has perthitic texture and is in close contact with pyroxene (Figure $8 \mathrm{a}$ and $8 \mathrm{~b}$ ). Apatite is needle-like and colourless, occurring as inclusions in feldspars (Figures 8c and 8d).

\section{Mineral Chemistry}

Pyroxene: The mineral composition of pyroxene in charnockitic gneiss shows a slight variation from core to rim (Table 1). The range in composition for both the core and rim is: $\mathrm{SiO}_{2}:$ 49.68-49.82\%, MgO: $15.20-15.07 \%$, FeO: $31.91-32.19 \%$ and $\mathrm{CaO}: 0.495-0.618 \%$. This result confirms the orthopyroxene as hypersthene and the formula can be written as $\mathrm{MgFeSi}_{2} \mathrm{O}_{6}$ (Table 1). In terms of the pyroxene end members, the formula can be written as $\mathrm{En}_{45} \mathrm{Fs}_{54} \mathrm{Wo}_{1}$ (Table 1). The BSE image shows no form of zoning (Figure 5b), while the compositional maps show the levels of element in the minerals (Figure 6). The compositional maps show high levels of magnesium $(\mathrm{Mg})$ and iron $(\mathrm{Fe})$, but a very low level of calcium (Ca) in the pyroxene (Px).

Amphibole: The composition of the various oxides is (Table 1): $\mathrm{SiO}_{2}: 42.45 \%, \mathrm{TiO}_{2}: 2.038 \%$, FeO: $18.10 \%, \mathrm{Al}_{2} \mathrm{O}_{3}: 10.39 \%, \mathrm{MgO}: 9.16 \%$, CaO: $11.30 \%, \mathrm{Na}_{2} \mathrm{O}: 1.53 \%, \mathrm{~K}_{2} \mathrm{O}: 1.41 \%$ and $\mathrm{Cl}$ : $0.071 \%$. The compositional maps (Figure 6) show amphibole with an appreciable amount of $\mathrm{Fe}, \mathrm{Ca}$ and $\mathrm{Mg}$ but very low $\mathrm{Na}$ content. The formula of the amphibole is $(\mathrm{K}, \mathrm{Na})(\mathrm{Ca}, \mathrm{Fe})_{2}(\mathrm{Mg}$, $\mathrm{Fe}, \mathrm{Ti}, \mathrm{Al})_{5}(\mathrm{Al}, \mathrm{Si})_{8} \mathrm{O}_{22}(\mathrm{OH})_{2}$ that is named as hornblende (Table 1).

Biotite: The chemical composition of biotite crystals is (Table 2): $\mathrm{SiO}_{2}: 34.71-35.95 \%$, FeO: $\quad 19.97-20.97 \%, \quad \mathrm{MgO}: \quad 9.64-10.15 \%$, $\mathrm{Al}_{2} \mathrm{O}_{3}: 13.35-14.14 \%, \mathrm{TiO}_{2}: 4.84-5.23 \%, \mathrm{CaO}:$ 0-0.07\% and $\mathrm{K}_{2} \mathrm{O}: 8.54-9.74 \%$. The elemental composition of the biotite shows that it is annite.

Plagioclase: The chemical composition of 14 crystals of plagioclase shows the following range of values: $\mathrm{SiO}_{2}$ : 58.14-60.19\%, $\mathrm{Al}_{2} \mathrm{O}_{3}: 24.06-25.77 \%$, $\mathrm{CaO}: 7.18-8.58 \%, \mathrm{Na}_{2} \mathrm{O}$ : $5.99-7.35 \%$ and $\mathrm{K}_{2} \mathrm{O}: 0.34-0.49 \%$, and in terms of anorthite content it can be written as $\mathrm{Ab}_{59} \mathrm{An}_{39} \mathrm{Or}_{2}$, that is known as andesine (Figure 9). The chemical formula of the plagioclase based on cations is (Na,Ca) $\mathrm{AlSi}_{3} \mathrm{O}_{8}$ (Table 3 ).

Table 1. The chemical composition of pyroxene and amphibole

\begin{tabular}{|c|c|c|c|c|c|c|c|c|c|}
\hline \multicolumn{3}{|c|}{ Pyroxene } & \multicolumn{6}{|c|}{ Amphibole } & \multirow[b]{2}{*}{6} \\
\hline Sample & $1 c$ & $1 r$ & Crystal & 1 & 2 & 3 & 4 & 5 & \\
\hline $\mathrm{SiO}_{2}$ & 49.680 & 49.830 & $\mathrm{SiO}_{2}$ & 42.453 & 41.804 & 43.680 & 42.904 & 43.139 & 42.786 \\
\hline $\mathrm{TiO}_{2}$ & 0.037 & 0.114 & $\mathrm{TiO}_{2}$ & 2.038 & 1.450 & 1.505 & 1.669 & 1.826 & 1.993 \\
\hline $\mathrm{Al}_{2} \mathrm{O}_{3}$ & 0.618 & 0.682 & $\mathrm{Al}_{2} \mathrm{O}_{3}$ & 10.389 & 10.342 & 9.819 & 10.039 & 10.174 & 10.186 \\
\hline $\mathrm{FeO}$ & 32.470 & 31.910 & $\mathrm{FeO}$ & 18.095 & 17.894 & 17.156 & 18.178 & 18.975 & 18.580 \\
\hline $\mathrm{Cr}_{2} \mathrm{O}_{3}$ & 0.000 & 0.010 & $\mathrm{Cr}_{2} \mathrm{O}_{3}$ & 0.000 & 0.000 & 0.043 & 0.132 & 0.053 & 0.101 \\
\hline $\mathrm{MnO}$ & 0.585 & 0.712 & $\mathrm{MnO}$ & 0.058 & 0.016 & 0.111 & 0.132 & 0.049 & 0.054 \\
\hline $\mathrm{MgO}$ & 15.200 & 15.070 & $\mathrm{MgO}$ & 9.163 & 9.361 & 9.943 & 9.474 & 9.399 & 9.622 \\
\hline $\mathrm{CaO}$ & 0.618 & 0.495 & $\mathrm{CaO}$ & 11.305 & 11.394 & 11.575 & 11.465 & 11.431 & 11.455 \\
\hline $\mathrm{Na}_{2} \mathrm{O}$ & 0.014 & 0.055 & $\mathrm{Na}_{2} \mathrm{O}$ & 1.533 & 1.338 & 1.108 & 1.386 & 1.406 & 1.443 \\
\hline $\mathrm{K}_{2} \mathrm{O}$ & 0.057 & 0.030 & $\mathrm{~K}_{2} \mathrm{O}$ & 1.409 & 1.430 & 1.215 & 1.411 & 1.347 & 1.349 \\
\hline Total & 99.290 & 98.900 & $\mathrm{Cl}$ & 0.071 & 0.085 & 0.063 & 0.077 & 0.043 & 0.140 \\
\hline $\mathrm{TSi}$ & 1.958 & 1.970 & Total & 96.510 & 95.110 & 96.180 & 96.740 & 97.79 & 97.610 \\
\hline
\end{tabular}


Table 1. The chemical composition of pyroxene and amphibole (continue)

Pyroxene

Amphibole

\begin{tabular}{|c|c|c|c|c|c|c|c|c|c|}
\hline Sample & $1 c$ & $1 r$ & Crystal & 1 & 2 & 3 & 4 & 5 & 6 \\
\hline TAl & 0.029 & 0.030 & O_Cl & 0.020 & 0.020 & 0.010 & 0.020 & 0.010 & 0.030 \\
\hline $\mathrm{TFe}^{3+}$ & 0.014 & 0.000 & $\mathrm{TSi}$ & 6.553 & 6.517 & 6.681 & 6.580 & 6.556 & 6.512 \\
\hline $\mathrm{M} 1 \mathrm{Al}$ & 0.000 & 0.002 & TAl & 1.447 & 1.483 & 1.319 & 1.420 & 1.444 & 1.488 \\
\hline M1Ti & 0.001 & 0.003 & Sum_T & 8 & 8 & 8 & 8 & 8 & 8 \\
\hline $\mathrm{M}_{1 F \mathrm{Fe}^{3+}}$ & 0.044 & 0.026 & CAl & 0.442 & 0.416 & 0.449 & 0.393 & 0.377 & 0.337 \\
\hline $\mathrm{M} \mathrm{Fe}^{2+}$ & 0.062 & 0.080 & $\mathrm{CFe}^{+3}$ & 0.000 & 0.038 & 0 & 0 & 0 & 0 \\
\hline $\mathrm{M} 1 \mathrm{Cr}$ & 0.000 & 0.000 & CTi & 0.237 & 0.170 & 0.173 & 0.193 & 0.209 & 0.228 \\
\hline $\mathrm{M} 1 \mathrm{Mg}$ & 0.893 & 0.888 & $\mathrm{CMg}$ & 2.109 & 2.176 & 2.267 & 2.166 & 2.129 & 2.183 \\
\hline $\mathrm{M} 2 \mathrm{Mg}$ & 0.000 & 0.000 & $\mathrm{CFe}^{+2}$ & 2.213 & 2.201 & 2.106 & 2.232 & 2.279 & 2.240 \\
\hline $\mathrm{M}_{2} \mathrm{Fe}^{2}$ & 0.950 & 0.949 & Sum_C & 5 & 5 & 5 & 5 & 5 & 5 \\
\hline M2Mn & 0.020 & 0.024 & $\mathrm{BFe}^{+2}$ & 0.123 & 0.095 & 0.089 & 0.099 & 0.132 & 0.125 \\
\hline $\mathrm{M} 2 \mathrm{Ca}$ & 0.026 & 0.021 & BMn & 0.008 & 0.002 & 0.014 & 0.017 & 0.006 & 0.007 \\
\hline $\mathrm{M} 2 \mathrm{Na}$ & 0.001 & 0.004 & $\mathrm{BCa}$ & 1.870 & 1.903 & 1.897 & 1.884 & 1.861 & 1.868 \\
\hline M2K & 0.003 & 0.002 & Sum_B & 2 & 2 & 2 & 2 & 2 & 2 \\
\hline $\begin{array}{l}\text { Sum } \\
\text { (cat) }\end{array}$ & 3.997 & 3.998 & $\mathrm{ANa}$ & 0.459 & 0.404 & 0.329 & 0.412 & 0.414 & 0.426 \\
\hline $\mathrm{Ca}$ & 1.337 & 1.069 & $\mathrm{AK}$ & 0.277 & 0.284 & 0.237 & 0.276 & 0.261 & 0.262 \\
\hline $\mathrm{Mg}$ & 45.770 & 45.260 & Sum_A & 0.736 & 0.689 & 0.566 & 0.688 & 0.675 & 0.688 \\
\hline Fe2_Mn & 52.890 & 53.670 & Sum_cat & 15.736 & 15.689 & 15.566 & 15.688 & 15.675 & 15.688 \\
\hline JD1 & 0.000 & 0.108 & $\mathrm{CCl}$ & 0.019 & 0.022 & 0.016 & 0.020 & 0.011 & 0.036 \\
\hline AE1 & 0.202 & 0.186 & Sum_oxy & 23.102 & 23.000 & 23.023 & 23.031 & 23.016 & 23.002 \\
\hline CFTS1 & 2.056 & 1.168 & & & & & & & \\
\hline CTTS1 & 0.056 & 0.174 & & & & & & & \\
\hline CATS1 & 0.000 & 0.000 & & & & & & & \\
\hline W01 & 0.000 & 0.000 & & & & & & & \\
\hline EN1 & 45.780 & 45.560 & & & & & & & \\
\hline FS1 & 51.902 & 52.800 & & & & & & & \\
\hline$Q$ & 1.931 & 1.939 & & & & & & & \\
\hline $\mathrm{J}$ & 0.002 & 0.008 & & & & & & & \\
\hline WO & 1.299 & 1.055 & & & & & & & \\
\hline EN & 44.460 & 44.670 & & & & & & & \\
\hline FS & 54.240 & 54.280 & & & & & & & \\
\hline WEF & 99.890 & 99.570 & & & & & & & \\
\hline JD & 0.000 & 0.032 & & & & & & & \\
\hline $\mathrm{AE}$ & 0.100 & 0.396 & & & & & & & \\
\hline
\end{tabular}

$M 1$, third octahedral site; $M 2$, second octahedral site; $M 3$, first octahedral site; T, tetrahedral site; $J D$, jadeite; $A E$, aegirine;

WO, wollastonite; EN, enstatite; FS, ferrosilite; CAT, cation. 
Table 2. Chemical composition of biotite crystals

\begin{tabular}{|c|c|c|c|c|c|c|c|c|}
\hline Crystal & 1 & 2 & 3 & 4 & 5 & 6 & 7 & 8 \\
\hline $\mathrm{SiO}_{2}$ & 35.20 & 35.10 & 35.19 & 34.71 & 35.52 & 35.34 & 35.95 & 35.42 \\
\hline $\mathrm{TiO}_{2}$ & 5.23 & 5.15 & 4.97 & 4.84 & 4.84 & 4.97 & 5.09 & 5.00 \\
\hline $\mathrm{Al}_{2} \mathrm{O}_{3}$ & 13.63 & 13.79 & 14.14 & 13.75 & 13.92 & 13.35 & 13.82 & 13.83 \\
\hline $\mathrm{Cr}_{2} \mathrm{O}_{3}$ & 0.04 & 0.06 & 0.00 & 0.03 & 0.02 & 0.05 & 0.03 & 0.00 \\
\hline $\mathrm{FeO}$ & 21.02 & 20.48 & 20.75 & 20.96 & 19.97 & 20.59 & 20.41 & 20.72 \\
\hline $\mathrm{MnO}$ & 0.00 & 0.04 & 0.03 & 0.03 & 0.00 & 0.01 & 0.00 & 0.02 \\
\hline MgO & 9.88 & 9.95 & 10.15 & 9.93 & 10.00 & 10.07 & 9.99 & 9.64 \\
\hline $\mathrm{CaO}$ & 0.01 & 0.07 & 0.00 & 0.04 & 0.02 & 0.00 & 0.00 & 0.04 \\
\hline $\mathrm{Na}_{2} \mathrm{O}$ & 0.13 & 0.11 & 0.09 & 0.14 & 0.09 & 0.08 & 0.14 & 0.11 \\
\hline $\mathrm{K}_{2} \mathrm{O}$ & 9.74 & 9.71 & 9.57 & 9.62 & 9.56 & 8.54 & 9.63 & 9.74 \\
\hline $\mathrm{Cl}$ & 0.15 & 0.11 & 0.12 & 0.15 & 0.09 & 0.09 & 0.10 & 0.10 \\
\hline $\mathrm{H}_{2} \mathrm{O}$ & 1.80 & 1.81 & 1.81 & 1.78 & 1.81 & 1.80 & 1.83 & 1.81 \\
\hline Total & 95.03 & 94.57 & 95.01 & 94.2 & 94.03 & 93.09 & 95.16 & 94.62 \\
\hline $\mathrm{Si}$ & 5.739 & 5.735 & 5.717 & 5.714 & 5.803 & 5.823 & 5.812 & 5.782 \\
\hline AlIV & 2.261 & 2.265 & 2.283 & 2.286 & 2.197 & 2.177 & 2.188 & 2.218 \\
\hline AlVI & 0.356 & 0.388 & 0.423 & 0.380 & 0.481 & 0.414 & 0.443 & 0.441 \\
\hline $\mathrm{Ti}$ & 0.641 & 0.633 & 0.607 & 0.599 & 0.595 & 0.616 & 0.619 & 0.614 \\
\hline $\mathrm{Fe}^{2+}$ & 2.866 & 2.798 & 2.819 & 2.885 & 2.729 & 2.837 & 2.759 & 2.829 \\
\hline $\mathrm{Cr}$ & 0.005 & 0.008 & 0.000 & 0.004 & 0.003 & 0.007 & 0.004 & 0.000 \\
\hline Mn & 0.000 & 0.006 & 0.004 & 0.004 & 0.000 & 0.001 & 0.000 & 0.003 \\
\hline $\mathrm{Mg}$ & 2.401 & 2.423 & 2.458 & 2.437 & 2.436 & 2.474 & 2.408 & 2.346 \\
\hline $\mathrm{Ca}$ & 0.002 & 0.012 & 0.000 & 0.007 & 0.004 & 0.000 & 0.000 & 0.007 \\
\hline $\mathrm{Na}$ & 0.041 & 0.035 & 0.028 & 0.045 & 0.029 & 0.026 & 0.044 & 0.035 \\
\hline $\mathrm{K}$ & 2.026 & 2.024 & 1.984 & 2.020 & 1.993 & 1.795 & 1.986 & 2.028 \\
\hline Cations & 16.338 & 16.327 & 16.323 & 16.381 & 16.270 & 16.170 & 16.263 & 16.303 \\
\hline $\mathrm{CCl}$ & 0.083 & 0.061 & 0.066 & 0.084 & 0.050 & 0.050 & 0.055 & 0.055 \\
\hline $\mathrm{OH}$ & 1.959 & 1.970 & 1.967 & 1.958 & 1.975 & 1.975 & 1.973 & 1.972 \\
\hline 0 & 24 & 24 & 24 & 24 & 24 & 24 & 24 & 24 \\
\hline $\mathrm{Fe} /(\mathrm{Fe}+\mathrm{Mg})$ & 0.5400 & 0.54 & 0.530 & 0.540 & 0.530 & 0.530 & 0.530 & 0.550 \\
\hline $\mathrm{Mg} /(\mathrm{Fe}+\mathrm{Mg})$ & 0.460 & 0.460 & 0.470 & 0.460 & 0.470 & 0.470 & 0.470 & 0.450 \\
\hline
\end{tabular}

AIIV, aluminium in tetrahedral site; AIVI, aluminium in octahedral site. 


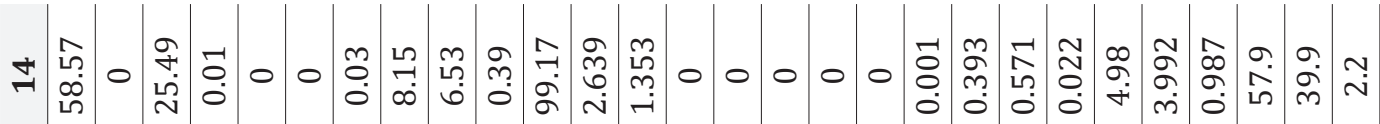

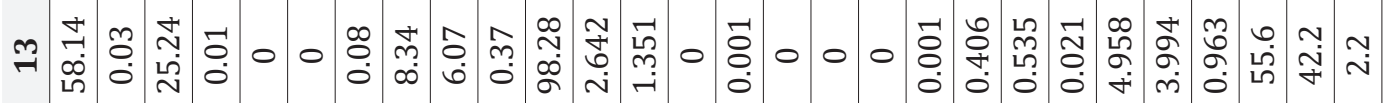

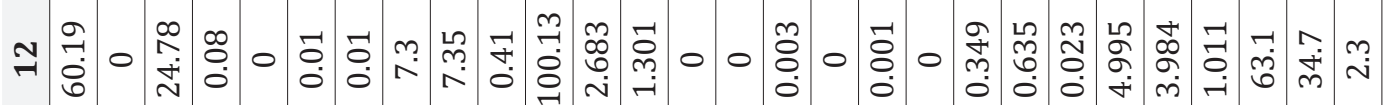

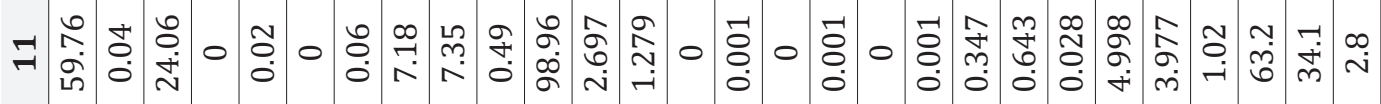

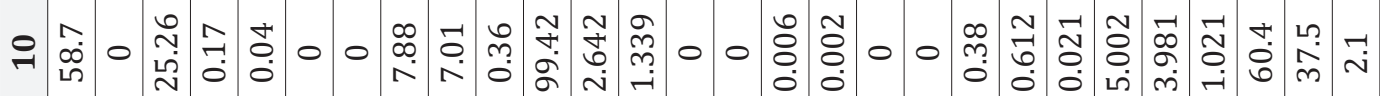

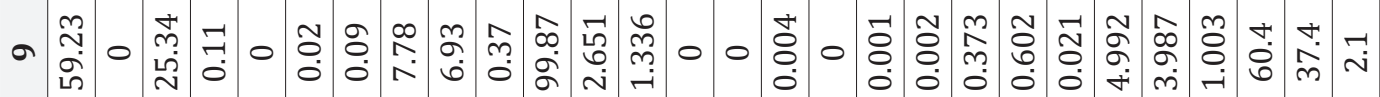

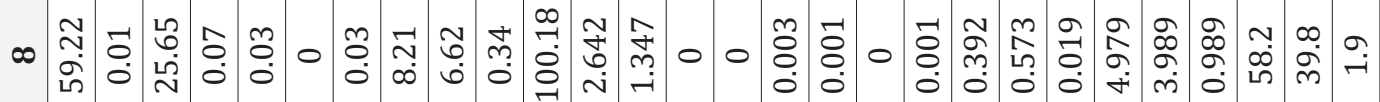

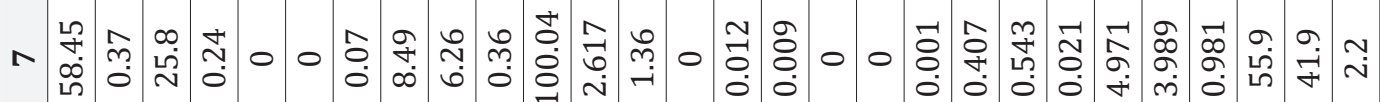

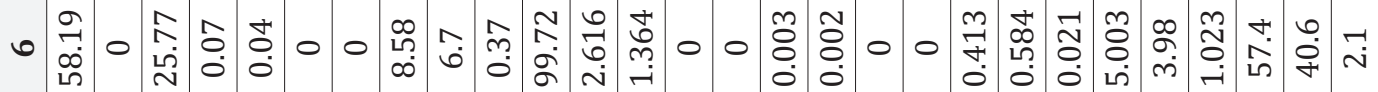

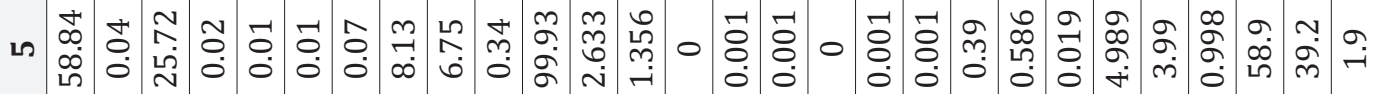

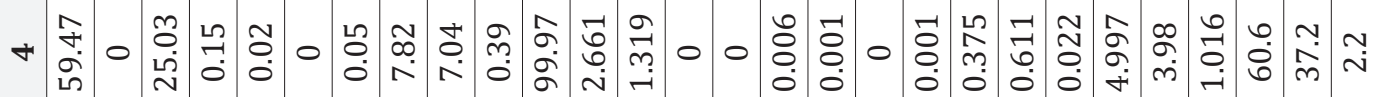
芒

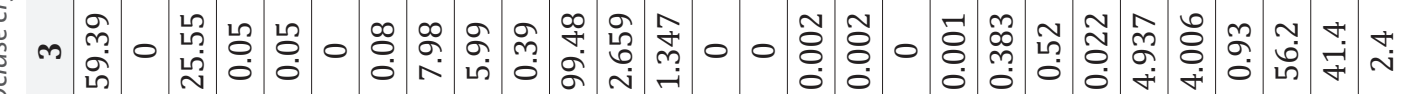
$\frac{10}{2}$

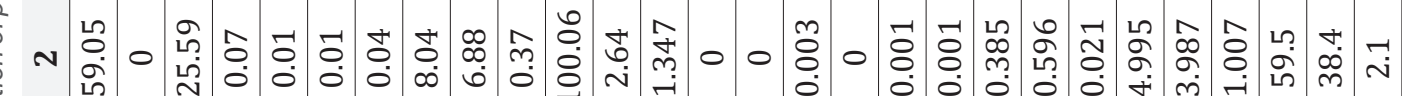
$\frac{1}{5}$

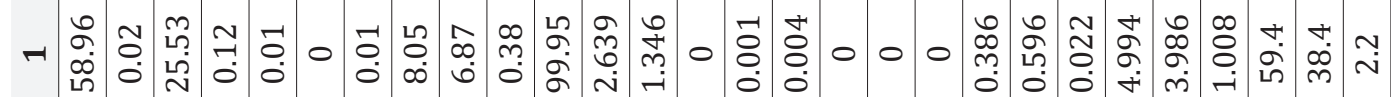

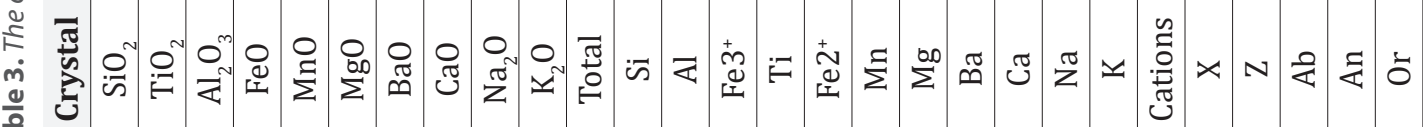

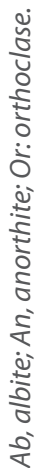




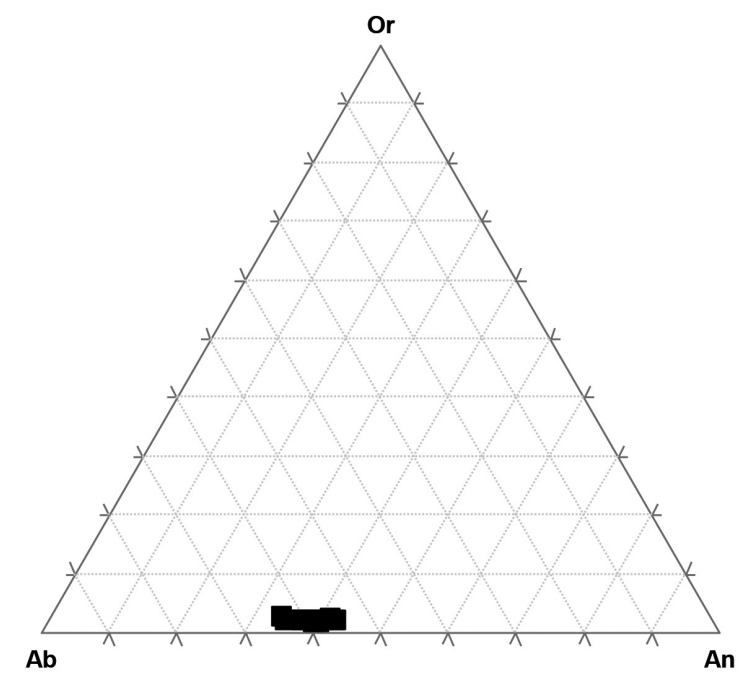

Figure 9. Ternary diagram showing feldspar solid solution.

Ilmenite: The result of the chemical composition of ilmenite for charnockitic gneiss shows the following values (Table 4): $\mathrm{TiO}_{2}: 50.79 \%$, FeO: $46.37 \%$ and $\mathrm{SiO}_{2}: 0.046 \%$.

\section{Major Element Geochemistry}

The composition of the major oxides is as follows (Table 5): $\mathrm{SiO}_{2}(50.93 \mathrm{wt} \%), \mathrm{Al}_{2} \mathrm{O}_{3}(15.51 \mathrm{wt} \%)$, $\mathrm{CaO}$ (7.79 wt\%), $\mathrm{Fe}_{2} \mathrm{O}_{3}$ (12.3 wt\%), $\mathrm{MgO}$ (5.14 wt\%), $\mathrm{K}_{2} \mathrm{O}$ (1.01 wt\%), MnO (0.15 wt\%), $\mathrm{Na}_{2} \mathrm{O}$ (3.33 wt\%), $\mathrm{TiO}_{2}$ (2.15 wt\%), $\mathrm{P}_{2} \mathrm{O}_{5}$ (0.65 wt\%), and $\mathrm{Cr}_{2} \mathrm{O}_{3}(0.02 \mathrm{wt} \%)$.

\section{Trace Element Geochemistry}

For the compatible elements $\mathrm{Zn}, \mathrm{Cr}$ and $\mathrm{V}$, the value ranges are as follows (Table 5): Zn (124.1 ppm), Cr (95.31 ppm) and V (188.28 ppm). The immobile transition elements $\mathrm{Co}$ and Ni have values of 107.09 and $52.36 \mathrm{ppm}$, respectively. The incompatible elements show a wide variation, and the large ion lithophile elements (LILE) have the values of Cs (0.31 ppm), Sr (583.8 ppm), Rb (18.36 ppm) and $\mathrm{Ba}(479.77 \mathrm{ppm})$.

\section{Rare Earth Elements Geochemistry}

The rare earth elemental (REE) composition of the charnockitic gneiss shows light REE (LREE) enrichment and depletion of heavy REE (HREE) (Table 5). The samples display a pattern of negative Eu anomaly.

\section{Discussion}

The orthopyroxene found in the charnockitic gneiss of Iboropa is hypersthene, that is Fe-Mgrich (Table 1) and it is associated with amphibole (hornblende) and plagioclase. Pyroxene analysed is a solid solution between enstatite and ferrosilite $\left(\mathrm{En}_{45} \mathrm{Fs}_{54} \mathrm{Wo}_{1}\right)$, and because of the high Fe content it can be referred to as ferrohypersthene. Orthopyroxene is an essential mineral for all rocks in the charnockite suite.

Table 4. The composition of ilmenite in a charnockitic gneiss

\begin{tabular}{|c|c|}
\hline Sample & 1 \\
\hline $\mathrm{SiO}_{2}$ & 0.046 \\
\hline $\mathrm{TiO}_{2}$ & 50.787 \\
\hline $\mathrm{Al}_{2} \mathrm{O}_{3}$ & 0.02 \\
\hline $\mathrm{FeO}$ & 46.372 \\
\hline $\mathrm{Cr}_{2} \mathrm{O}_{3}$ & 0.075 \\
\hline $\mathrm{MnO}$ & 0.477 \\
\hline $\mathrm{MgO}$ & 0.267 \\
\hline $\mathrm{CaO}$ & 0 \\
\hline $\mathrm{Na}_{2} \mathrm{O}$ & 0.061 \\
\hline Total & 98.11 \\
\hline $\mathrm{Si}$ & 0.001 \\
\hline $\mathrm{Al}$ & 0.001 \\
\hline $\mathrm{Ti}$ & 0.986 \\
\hline $\mathrm{Fe}^{2+}$ & 1.001 \\
\hline $\mathrm{Cr}$ & 0.002 \\
\hline $\mathrm{Mn}$ & 0.01 \\
\hline $\mathrm{Mg}$ & 0.01 \\
\hline $\mathrm{Ca}$ & 0 \\
\hline $\mathrm{Na}$ & 0.003 \\
\hline Cations & 2.014 \\
\hline
\end{tabular}

The percentage of $\mathrm{CaO}$ in the analysed pyroxene is very low $(0.5-0.6 \%)$, a value which is less than 1.0 and is consistent with the fact that $\mathrm{Ca}$ atoms per formula does not exceed 1.0, which occurs only in the M2 site [30]. The aluminium oxide content of the pyroxene is also low. Orthopyroxene can be found to be metamorphic because the weight percentage of $\mathrm{MgO}+\mathrm{FeO}_{\mathrm{T}}$ is greater than $44.00 \%$ [31]. Orthopyroxene present could have formed during increase in grade of metamorphism from either hornblende or biotite. In Northern Nigeria, charnockite has been derived from the transformation of biotite by the addition of ferrous iron-rich juvenile 
Table 5. Bulk rock composition of charnockitic gneiss; major elements (\%), trace elements (ppm), REE (ppm)

\begin{tabular}{|c|c|c|c|c|c|}
\hline Major element & 1 & Trace element & 1 & REE & 1 \\
\hline $\mathrm{Wt} \%$ & & ppm & & ppm & \\
\hline $\mathrm{SiO}_{2}$ & 50.93 & $\mathrm{~V}$ & 188.28 & $\mathrm{La}$ & 57.71 \\
\hline $\mathrm{Al}_{2} \mathrm{O}_{3}$ & 15.51 & $\mathrm{Cr}$ & 95.31 & $\mathrm{Ce}$ & 119.2 \\
\hline $\mathrm{CaO}$ & 7.79 & $\mathrm{Co}$ & 107.09 & $\mathrm{Pr}$ & 14.13 \\
\hline $\mathrm{Fe}_{2} \mathrm{O}_{3}$ & 12.3 & $\mathrm{Ni}$ & 52.36 & $\mathrm{Nd}$ & 54.64 \\
\hline $\mathrm{MgO}$ & 5.14 & $\mathrm{Cu}$ & 41.17 & $\mathrm{Sm}$ & 9.05 \\
\hline $\mathrm{K}_{2} \mathrm{O}$ & 1.01 & $\mathrm{Zn}$ & 124.1 & $\mathrm{Eu}$ & 2.27 \\
\hline $\mathrm{MnO}$ & 0.15 & $\mathrm{Rb}$ & 18.36 & $\mathrm{Gd}$ & 7.325 \\
\hline $\mathrm{Na}_{2} \mathrm{O}$ & 3.33 & $\mathrm{Sr}$ & 583.8 & $\mathrm{~Tb}$ & 0.856 \\
\hline $\mathrm{TiO}_{2}$ & 2.15 & $\mathrm{Zr}$ & 294.09 & Dy & 4.365 \\
\hline $\mathrm{P}_{2} \mathrm{O}_{5}$ & 0.65 & $\mathrm{Nb}$ & 20.61 & Ho & 0.8 \\
\hline $\mathrm{Cr}_{2} \mathrm{O}_{3}$ & 0.02 & Mo & 1.54 & Er & 2.02 \\
\hline LOI & 0.34 & $\mathrm{Cs}$ & 0.31 & $\mathrm{Tm}$ & 0.251 \\
\hline \multirow[t]{7}{*}{ Total } & 99.32 & $\mathrm{Ba}$ & 479.77 & $\mathrm{Yb}$ & 1.63 \\
\hline & & Hf & 6.49 & $\mathrm{Lu}$ & 0.22 \\
\hline & & $\mathrm{Ta}$ & 1.08 & Total & 274.4 \\
\hline & & $\mathrm{Pb}$ & 8.51 & $\mathrm{La}_{\mathrm{N}} / \mathrm{Yb}_{\mathrm{N}}$ & 25.39 \\
\hline & & Th & 2.89 & $\mathrm{Gd}_{\mathrm{N}} / \mathrm{Yb}_{\mathrm{N}}$ & 3.72 \\
\hline & & $\mathrm{U}$ & 0.45 & $\mathrm{Eu}_{\mathrm{N}} / \mathrm{Eu}_{\mathrm{N}}{ }^{*}$ & 0.852 \\
\hline & & & & $\mathrm{Ce} / \mathrm{Ce}^{*}$ & 1.153 \\
\hline
\end{tabular}

solution [32]. Orthopyroxene could be formed by any of the following reactions:

Hornblende + Quartz $=>$

Clinopyroxene + Orthopyroxene +

Plagioclase $+\mathrm{K}$-feldspar $+\mathrm{H}_{2} \mathrm{O}$

Biotite + Quartz $=>$

Orthopyroxene $+\mathrm{K}$-feldspar $+\mathrm{H}_{2} \mathrm{O}$

The earlier reactions are dehydration reactions resulting in a decrease in the activity of water and an increase in alkali activity [19]. Mineral assemblage show altered form of biotite (first-generation biotite) in close association with K-feldspar (Figure 8a). This process is a high-grade dehydration of rocks of the amphibolite facies to granulite facies and it can involve partial melting and in some cases fluid solid-state dehydration [33-35]. Orthopyroxene mantled by amphibole is an indication of retrogressive metamorphic event (Figure 5). The retrogression of the charnockite could be due to various dehydration processes [36]. Retrogression involving the breakdown of orthopyroxene is quite common in granulite complexes $[37,38]$. Orthopyroxene replaced by amphibole has been described in the granulite facies of gneiss in the granite Falls-Montevideo [39]. The hypersthene observed has numerous microfractures that may serve as a pathway for the movement of fluids (Figure 4a). The development of biotite along cleavage planes (Figure $4 \mathrm{a}$ ) is also an indication of retrogression [40]. Amphibole could have been formed by a process in which orthopyroxene reacts with plagioclase (anorthite-rich) and quartz in the presence of water, and this can be represented by the following equation:

Orthopyroxene + Plagioclase $1+$ Quartz $+\mathrm{H}_{2} \mathrm{O}=>$ Amphibole + Plagioclase 2 
In this process, amphibole replaces orthopyroxene in a rehydration reaction. Biotite (second-generation biotite) that is in close contact with orthopyroxene (Figure 4a) could have been a product of a reaction in which K-feldspar is consumed by a rehydration process, and thus it can be represented by the following equation:

Orthopyroxene $+\mathrm{K}$-feldspar $+\mathrm{H}_{2} \mathrm{O}=>$ Biotite

The biotite is annite-rich, an iron end member of biotite as indicated by the mineral chemistry (Table 2). Such retrogressive reactions have been found to result from fluid $\left(\mathrm{CO}_{2}\right.$ and $\mathrm{H}_{2} \mathrm{O}$ ) activity and oxygen fugacity in the later stages of dehydration zone [41]. Based on the BSE image and elemental maps (Figures $5 b$ and 6), there is no evidence of zoning in the pyroxene crystals. Hornblende and biotite in charnockites have been found to be due to retrogressive metamorphism of pyroxene granulite facies rocks $[42,43]$, and retrograde form of metamorphism has been found to obliterate the mineralogy of the granulite facies [24]. Plagioclase occurring as inclusions in pyroxene and biotite is an indication that it was formed very early enough as primary minerals. Opaque minerals that are concentrated along the cleavage planes of amphiboles crystals are evidences of metamorphic alteration. The $\mathrm{Al}_{2} \mathrm{O}_{3}$ content of the amphibole is fairly high, and chornockitic rocks usually have $\mathrm{Al}_{2} \mathrm{O}_{3}$ higher than that of the normal igneous rocks. Hornblende has less magnesium than the coexisting orthopyroxene and a moderate composition of $\mathrm{TiO}_{2}(2.04 \%)$. Hornblende has high $\mathrm{TiO}_{2}(>2)$ which some authors have linked to the increase in the grade of metamorphism, and this link between temperature and Ti content of amphibole has been reported $[44,45]$. There is a high value of $\mathrm{TiO}_{2}$ (4.84-5.23\%) in biotite, an indication that it is uniformly rich in $\mathrm{Ti}$, and a higher value of $\mathrm{X}_{\mathrm{Fe}}$ to $\mathrm{X}_{\mathrm{Mg}}$. Biotite could have reacted with quartz to give the Fe-Ti ilmenite. There has been suggestion that increasing Ti content leads to increase in the stability field of biotite [46]. The crystals of biotite have $\mathrm{MgO}$ of nearly the same range of composition as that of amphiboles but far less than that of orthopyroxene. Plagioclase is the dominant feldspar observed and it is al- bite-enriched $\left(\mathrm{Ab}_{55.9} \mathrm{An}_{41.9} \mathrm{Or}_{2.2}-\mathrm{Ab}_{63.2} \mathrm{An}_{34.1} \mathrm{Or}_{2.8}\right)$ that is andesine and is indicative of amphibolite zone. The K-feldspar has perthitic texture (Figure $8 \mathrm{~b})$. Perthite is an intergrowth of one feldspar within another, albite in orthoclase [47], and it is common in high-grade metamorphic rocks [48] due to the high temperature involved. The perthite observed has straight lamellae (Figure $7 \mathrm{~b}$ ), an indication of granulite facies. Based on the association of orthopyroxene and plagioclase, the granulite can be said to be of intermediate pressure [24], and one of the feature of this facies is the depletion of Th and $\mathrm{U}$. The values of Cs have also been found to be depleted in high-grade metamorphosed rocks [24]. There is a depletion in the values of $\mathrm{K}, \mathrm{Rb}$, Th and $\mathrm{U}$, and pyroxene gneiss with values of this nature has been suggested as a residue of partial melting in which there has been the removal of these elements from the original rocks [49]. The elements $\mathrm{Th}, \mathrm{U}, \mathrm{Rb}$ and Cs are usually present in the lattices of micas of the amphibolite facies but there is breaking down of micas to K-feldspar in the granulite facies, and $\mathrm{K}$-feldspar do not concentrate $\mathrm{Rb}$ and Cs [24]. The Sr value in this rock is high, which might compound the low value of $\mathrm{Rb}$, thus giving rise to low $\mathrm{Rb} / \mathrm{Sr}$ ratio. REE patterns show LREE enrichment, and HREE-depleted patterns with negative Eu anomaly (Table 5), suggesting that this charnockitic gneiss of Iboropa could have been formed by partial melting and crystallisation. The enrichment of LREE and negative Eu anomaly are similar to the charnockitic rocks of Ado-Ekiti area of Nigeria [50]. The negative Eu anomaly reflects an intracrustal form of differentiation of the original igneous parent rock [51].

\section{Conclusion}

The detailed petrographic observation and the mineral assemblage suggest a retrograde metamorphic reaction. There are two generations each for biotite and plagioclase feldspar. The first-generation biotite is altered and it is concentrated in and around plagioclase as well as K-feldpar, while the second-generation biotite surrounds orthopyroxene. The high-grade minerals such as hypersthene and plagioclase gave 
rise to hydrous minerals amphiboles and biotite. Fluids responsible for the hydration reaction could have been transported along the numerous microfractures within the hypersthene grains. The presence of straight lamellae in the perthite is an evidence of granulite facies. The charnockitic gneiss could have been resulted from a partial melting process.

\section{Acknowledgements}

The use of JEOL JXA 8230 Superprobe, instrument sponsored by NRF/NEP grant 40113 (UID 74464) at Rhodes University, Grahamstown South Africa, is kindly acknowledged. The financial support from Tertiary Education Trust Fund (TETFUND) is recognised.

\section{References}

[1] Holland, T.H. (1900): The charnockite series, a group of Archean hypersthenic rocks in Peninsular India. Memoir Geological Survey of India, 28, 192-249.

[2] Anantha, I., T.R., N.K. (1978): Geochemical Comparison of Archaean Granulites in India with Proterozoic Granulites in Canada.

[3] Dobmeier, C., Raith, M.M. (2000): On the origin of 'arrested' charnockitization in the Chilka Lake area, Eastern Ghats Belt, India: a reappraisal. Geological Magazine, 137(1), pp. 27-37.

[4] Ghosh, J.G., de Wit, M.J., Zartman, R.E. (2004): Age and tectonic evolution of Neoproterozoic ductile shear zones in the Southern Granulite Terrain of India, with implications for Gondwana studies. Tectonics, 23(3), pp. 1-38.

[5] Rajesh, H.M., Santosh, M. (2004): Charnockitic magmatism in southern India. Proceedings of the Indian Academy of Sciences - Earth \& Planetary Sciences, 113(4), pp. 565-585.

[6] Le Maitre, R.W. (2002): Igneous Rocks: A Classification and Glossary of Terms. Cambridge University Press: Cambridge, $256 \mathrm{p}$.

[7] Frost, B.R., Frost, C.D. (2008): On charnockites. Gondwana Research, 13, pp. 30-44.

[8] Rajesh, H.M., Santosh, M. (2012): Charnockites and charnockites. Geoscience Frontiers, 3, pp. 737 -744.

[9] Janardhan, A.S., Jayananda, M., Shankara, M.A. (1994): Formation and tectonic evolution of granulites from Biligirirangam and Nilgiri Hills, south In- dia: Geochemical and isotopic constraints. Journal of the Geological Society of India, 44, pp. 27-40.

[10] Friend, C.R.L. (1981): Charnockite and granite formation and influx of $\mathrm{CO}_{2}$ at Kabbaldurga. Nature, 294, pp. 550-552.

[11] Hansen, E.C., Janardhan, A.S., Newton, R.C., Prame, W.K.B., Kumar, G.R.R. (1987): Arrested charnockite formation in southern India and Sri Lanka. Contributions to Mineralogy and Petrology, 96, pp. 225-244.

[12] Srikantappa, C., Raith, M., Touret, J.L.R. (1992): Synmetamorphic high-density carbonic fluids in the lower crust: evidence from the Nilgiri granulites, Southern India. Journal of Petrology, 33(4), pp. 733-760.

[13] Raith, M., Srikantappa, C. (1993): Arrested charnockite formation at Kottavattam, Southern India. Journal of Metamorphic Geology, 11(6), pp. 815-832.

[14] Harley, S.L., Santosh, M. (1995): Wollastonite at Nuliyam, Kerala, South India: A reassessment of $\mathrm{CO}_{2}$ infiltration and charnockite formation at a classic locality. Contributions to Mineralogy and Petrology, 120, pp. 83-94.

[15] Yoshida, M., Santosh, M. (1994): A tectonic perspective of incipient charnockites in East Gondwana. Precambrian Research, 66(1-4), pp. 379-392.

[16] Newton, R.C., Hansen, E.C. (1983): The origin of Proterozoic and late Archaean charnockites-evidence from field relations and experimental petrology. Geological Society of America Memorials, 161, pp. 167-178.

[17] Condie, K.C., Bowling, G.P., Allen, P. (1986): Origin of granites in an Archean high-grade terrane, southern India. Contributions to Mineralogy and Petrology, 92(1), pp. 93-103.

[18] Bhattacharya, S. (2010): The charnockite problem, a twenty first century perspective. Natural Science, 2(04), p. 402.

[19] Perchuk, L.L., Gerya, T.V. (1993): Fliud control of charnockitization. Chemical Geology, 108, pp 175-186.

[20] Touret, J.L., Huizenga, J.M. (2012): Fluid-assisted granulite metamorphism: a continental journey. Gondwana Research, 21(1), pp. 224-235.

[21] Yang, Q.Y., Santosha, M., Tsunogaec, T. (2014): First report of Paleoproterozoic incipient charnockite from the North China Craton: Implications for ultrahigh-temperature metasomatism. Precambrian Research, 243, pp. 168-180.

[22] Rahaman, M.A. (1976): Review of the basement geology of Southwestern Nigeria. In: Geology of Ni- 
geria, C.A. Kogbe (ed.). Elizabethan Publishing Co.: Lagos, pp. 41-58.

[23] Rahaman, M.A., Ocan, O. (1978): On relationships in the Precambrian migmatitic gneisses of Nigeria. $\mathrm{Ni}$ gerian Journal of Mining and Geology, 15, pp. 23-32.

[24] Heier, K.S. (1973): A Discussion on the evolution of the Precambrian crust-Geochemistry of granulite facies rocks and problems of their origin. Philosophical Transactions of the Royal Society of London. Series A, Mathematical and Physical Sciences, 273(1235), pp. 429-442.

[25] Hubbard, F.H. (1975): Precambrian crustal development in western Nigeria: indications from the Iwo region. Bulletin of the Geological Society of America, 86, pp. 548-554.

[26] Ferré, E.C., Caby, R. (2007): Granulite facies metamorphism and charnockite plutonism: examples from the Neoproterozoic Belt of northern Nigeria. Proceedings of 'the Geologists' Association, US, 47-54.

[27] Sacchi, R. (1968): The geology of Kabba-Lokoja region in south-western Nigeria. Bolletino della Società geologica italiana, 87, 341-367.

[28] Dempster A.N. (1967): (GSN). 1:250,000 Sheet 61, Akure.

[29] Rahaman, M.A., Ocan, O. (1988): The Nature of Granulite of Granulite Facies Metamorphism in Ikare Area, Southwestern Nigeria. In: Precambrian Geology of Nigeria. GSN pub., pp. 157-163.

[30] Cameron, M., Papike, J.J. (1981). Structural and chemical variations in pyroxenes. American Mineralogist, 66(1-2), pp. 1-50.

[31] Bhattacharyya, C. (1971): An evaluation of the chemical distinctions between igneous and metamorphic orthopyroxenes. American Mineralogist: Journal of Earth and Planetary Materials, 56(3-4_Part_1), pp. 499-506.

[32] Oyawoye, M.O. (1964): The contact relationship of charnockite and granite gneiss at Bauchi, Northern Nigeria: Geological Magazine, v. 101, pp. 138-144.

[33] Harlov, D.E., Johansson, L., Van Den Kerkhof, A., Förster, H.J. (2006a): The role of advective fluid flow and diffusion during localized, solid-state dehydration: Söndrum Stenhuggeriet, Halmstad, SW Sweden. Journal of Petrology, 47(1), pp. 3-33.

[34] Rigby, M.J., Droop, G.T.R. (2011): Fluid-absent melting versus $\mathrm{CO} 2$ streaming during the formation of pelitic granulites: A review of insights from the cordierite fluid monitor. Origin and evolution of Precambrian high-grade gneiss terranes, with special emphasis on the Limpopo complex of Southern Africa, 207, p. 39.

[35] Harlov, D.E. (2012): The potential role of fluids during regional granulite-facies dehydration in the lower crust. Geoscience Frontiers, 3(6), pp. 813-827.

[36] Ravindra Kumar, G.R., Chacko, T. (1986): Mechanisms of charnockite formation and breakdown in southern Kerala: implications for the origin of the southern Indian granulite terrain. Journal of the Geological Society of India, 28(4), pp. 277-288.

[37] Lasnier, B. (1977): Persistance d'une série granulitique au coeur du Massif Central français, Haut-Allier: les termes basiques, ultrabasiques et carbonates. Ph.D. Thesis. Université de Nantes, laboratoire de pétrologie et de minéralogie: Nantes, $351 \mathrm{p}$.

[38] Srikantappa, C., Prakash Narasimha, K.N. (1988): Retrogression of charnockites in Moyar Shear Zone, Tamil Nadu. Journal of the Geological Society of India, 11, pp. 117-124.

[39] Himmelberg, G.R., Phinney, W.C. (1967): Granulite-Facies Metamorphism, Granite Falls-Montevideo Area, Minnesota. Journal of Petrology, 8(3), pp. 325-348.

[40] Allen, P., Condie, K.C., Narayana, B.L. (1985): The geochemistry of prograde and retrograde charnockite-gneiss reactions in southern India. Geochimica et Cosmochimica Acta, 49(2), pp. 323-336.

[41] Oyawale, A.A., Ocan O.O. (2020): Migmatization process and the nature of transition from amphibolite to granulite facies metamorphism in Ikare area Southwestern Nigeria. Journal of Geology and Mining Research, 12(2), pp. 45-64.

[42] Cooray, P.G. (1961): The Geology of the area around Rangala: Ceylon Geol. Survey Mem., 2, 138 p.

[43] Cooray, P.G. (1962): Charnockites and their associated gneisses in the Pre-Cambrian of Ceylon. The Quarterly journal of the Geological Society of London, 118, pp. 239-273.

[44] Raase, P. (1974): Al and Ti contents of hornblende, indicators of pressure and temperature of regional metamorphism. Contributions to mineralogy and petrology, 45(3), pp. 231-236.

[45] Spear, F.S. (1981): An experimental study of hornblende stability and compositional variability in amphibolite. American Journal of Science, 281(6), pp. 697-734.

[46] Dymek, R.F. (1983): Titanium, aluminum and interlayer cation substitutions in biotite from high-grade gneisses, West Greenland. American Mineralogist, 68(9-10), pp. 880-899. 
[47] Spry, A. (1969): Metamorphic Textures. Pergamon Press, Oxford: England, 358 p.

[48] Cayzer, N. (2002): Feldspar microtextures and the cooling histories of high-grade terrains. Ph.D. Thesis. University of Edinburgh, U.K., 300 p.

[49] Fyfe, W.S. (1973): The granulite facies, partial melting and the Archaean crust. Philosophical Transactions of the Royal Society of London. Series A, 273, pp. 457-461.

[50] Olarewaju, V.O. (1987): Charnockite-granite association in SW Nigeria: rapakavi granite type and charnockitic plutonism in Nigeria? Journal of African Earth Sciences, 6(1), pp. 67-77.

[51] Bhattacharya, S. Chaudhary, A.K., Basei, M. (2012): Original nature and source of Khondalites in the Eastern Ghats Province, India. Geological Society, London, Special Publications, 365, 147-159. 